\title{
Role of Arbuscular Mycorrhizal Fungi in Mulberry Ecosystem Development
}

\author{
Ghulam Hassan Dar* and Pankaj Dunge \\ Department of Agriculture, Mandsaur University, Rewas-Dewdra Road, \\ Mandsaur, Madhya Pradesh - 458001 (India) \\ *Corresponding author
}

\section{Ke y w o r d s \\ Arbuscular mycorrhizal fungi, mulberry, nutrition, plant growth, biocontrol, ecosystem \\ Article Info \\ Accepted: \\ 05 April 2020 \\ Available Online: \\ 10 May 2020}

\section{A B S T R A C T}

\section{Introduction}

The biological and logical values of woody trees in sustaining a sound ecosystem are immense. Trees, mostly used for timber, fuel and fodder purposes, play vital role in the restoration, reclamation and rejuvenation of denuded and disturbed soils and in shaping the sustainable ecosystem. Of these trees, mulberry (Morus sp.) tree has immense significance primarily due to its food value for silk worms (Bombyx mori L.), besides being a minor fruit crop and producing valuable timber.

Mulberry is practically the sole food of silkworm; therefore, the quality mulberry foliage predominantly influences the development of worm and quality of cocoon. Silk worm rearing is one of the most profitable enterprises for small and marginal farmers, especially in developing countries. Silk worm rearing mainly relies on mulberry leaves which are highly palatable and edible 
to these herbivorous animals due to high protein (15-28\%) and mineral contents (Petkov 2016). The quality cocoon production is directly correlated with mulberry foliar quality which contributes about $38.2 \%$ to successful rearing/quality cocoon production (Bothikar et al., 2014). So better the quality of mulberry foliage, the greater is the possibility of having good cocoon crops.

China is the largest silk producer in the world which produced 1,20,000 $\mathrm{t}$ silk in the year 2018, followed by India $(35,261$ t) [International Sericulture Commission 2019]. With present day focus on ecologically sustainable farming, the thrust in mulberry cultivation is on the practices which do not harm the silkworm quality and production. Mulberry is one of a few plants, that thrives for many years even with the incessant annual removal of all vegetative mass. Leaves produced are harvested by leaf picking or by cutting the whole branches. In terms of digestible nutrients, mulberry yields foliage which can serve as a supplement to the concentrates for dairy cattle or as feed for small ruminants or as ingredient in monogastric diets. To boost foliage and wood production, attention to the factors limiting mulberry growth is essential.

Though the yield of mulberry foliage may be enhanced by crop improvement and adoption of better production cum protection practices, yet it is the proper crop management which pays better dividends to the farmers. Mulberry plant has the ability to survive in nutritionally poor soil, however its growth is hampered when grown in infertile soil. Various biotic or abiotic components like the presence of beneficial microbes, proper management, adequate fertilization, etc. promote better growth and qualitative foliage in mulberry (Setua et al., 2007; Fernandez et al., 2014). Arbuscular mycorrhizal fungi (AMF) play a vital role in plant establishment and survival under adverse growth conditions and is associated for mutual benefits with more than $80 \%$ vascular plants including mulberry in terrestrial ecosystems (Smith \& Read 2008; Brundrett 2009). Mycorrhizal symbionts utilize up to $30 \%$ host photosynthates and, in turn, provide around $80 \%$ of nutrients and water to the host plant (Kilvin \& Hawkes 2016). Mycorrhiza have significant role in nutrient mobilization and uptake by mulberry plants. The integrated use of these bioinoculants is expected to ensure sustained productivity of mulberry and assure sustainable ecological farming. The present paper reviews the literature available on the role of mycorrhizae as bioinoculant in improving the growth and development of mulberry.

\section{Poor soil quality - a limitation to mulberry yield improvement}

The soil quality has profound influence on the quality and quantity of foliage which ultimately affects the cocoon yield. Mulberry plant is a deep-rooted perennial, mostly grown on sloppy and marginal lands due to great pressure on land for agriculture and horticulture (Gupta \& Arora 2015). Such soils are generally less fertile and need extraordinary aftercare to maintain sustained plant growth. Heavy dose of compost or farm yard manure $\left(10-20 \mathrm{t} \mathrm{ha}^{-1} \mathrm{yr}^{-1}\right)$, proper drainage, adequate fertilizer-use and irrigation help in improving the plant survivability and productivity (Seth 2003; Dandin et al., 2003). Surveys conducted by the Department of Sericulture, UAS, Bangalore (India) have revealed that in spite of the increase in area under mulberry cultivation with concomitant increase in cocoon production, there has been no improvement in silk quality, despite the use of new mulberry varieties and improved silkworm strains/races (Shankar et al., 1999). The main reasons for this are: inadequate fertilizer use, lack of soil testing, inadequate irrigation, improper spacing, etc. For instance, the available nutrient status of mulberry 
garden soils in Mysore, Karnataka (India) has revealed $76 \%$ soils were low in organic carbon while available nitrogen and available phosphorus $\left(\mathrm{P}_{2} \mathrm{O}_{5}\right)$ were low in 98 and $45 \%$ soils, respectively (Sudhakar et al., 2018). Further, $\mathrm{P}_{2} \mathrm{O}_{5}$ was medium in $23 \%$ soils, while available potassium $\left(\mathrm{K}_{2} \mathrm{O}\right)$ was medium in $49 \%$ and low in $20 \%$ soils. Most soils despite having abundant phosphorus are deficient in available phosphorus so mycorrhiza is a helping hand to mulberry plant which, except in organized farms, is generally grown under harsh conditions.

\section{AMF - structure and function}

AMF are obligate symbionts belonging to the phylum Glomeromycota which has three classes Glomeromycetes (with three orders Glomerales, Gigaspoarales and Diversisporales), Paraglomeromycetes (with order Paraglomales) and Archarsporomycetes (with order Archaeosporales) [Goto et al., 2012]. At present AM fungi are distributed into 15 families and 31 genera (Kheri et al., 2018). Glomus, Paragolomus, Septoglomus, Gigaspora, Funneliformis, Scutellospora, Sclerocystis, Acaulospora and Entrophospora are the main AM fungi (Fig. 1). On mutual association with living roots, AM fungi produce hyphae, arbuscules, vesicles and spores inside root cortex; and hyphae, vesicle and spores outside the roots, with the exception that in family Gigasporaceae AMF produce auxiliary cells instead of vesicles (Kheri et al., 2018). There is no known sexual state for most of these fungi and they only produce microscopic structures. The spores are separated from soil and categorized on the basis of their size, shape, colour, ornamentation, hyphal attachment, etc. (Souza 2015). So far there are 230 described AMF species (Glomeromycota species listed at www.amfphylogeny.com). DNA sequence information is presently available only for about $50 \%$ of the known species and only 81 species are available as cultures from various culture collection sources like International Culture Collection of (Vesicular) Arbuscular Mycorrhizal Fungi [INVAM]; Centre for Mycorrhizal Culture Collection [CMCC]; International Bank of the Glomeromycota [IBG]; Mycorrhiza.be; Glomeromycota In vitro Collection [GINCO]; (Declerck et al., 2005; Fortin et al., 2005). Reports have revealed that much of the functional diversity of AMF occurs at isolate level rather than at species level (Giovannini et al., 2020). Consequently, habitat information is as important as the knowledge about the taxonomic placement of fungi for comparison of experimental results or for selection of isolates for field application. Experimental evidences show that the performance of fungal isolates in improving the host plant growth is related to the environmental factors (Zhang et al., 2019).

The classification of AMF though primarily based on the structure of their soil-borne resting spores has gone through immense changes due to recent innovative studies on developmental processes, biochemical properties and molecular characterization of these fungi (Peterson et al., 2004). Accurate identification of AM fungi often requires culture isolation in culture with host plants to closely monitor the various developmental stages and avoid any loss of diagnostic feature which may occur in the samples collected from field. AMF infect almost all the plants and develop mutual symbiotic relationship. They penetrate the living cells of host plant without harming them, and form typical organs such as vesicles and arbuscules in roots (Fig. 2). Besides, fungal hyphae proliferate deep into the bulk soil and make nutrient, especially phosphorus, available to the plant beyond the nutrient depletion zone. By doing so, the AM fungi not only connect the plant with soil but also with neighbouring plants and transfer mineral nutrients to host and carbon compounds to soil and its biota. 

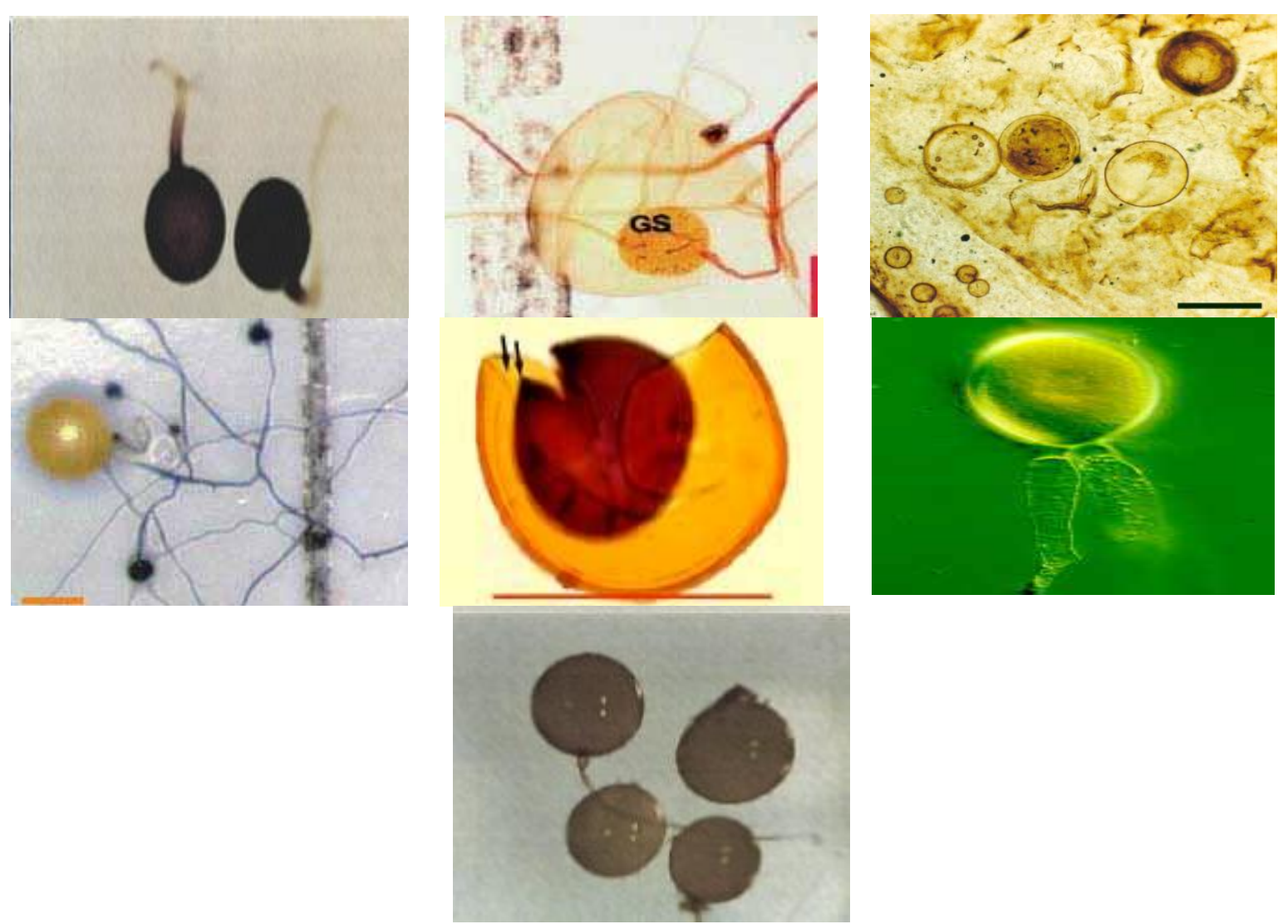

Fig.1 Arbuscular mycorrhizal fungi a) Glomus mosseae; b) Scutellospora, c) Sclerocystis; d) Gigaspora; e) Acaulospora f) Endogone; g) A germinating spores

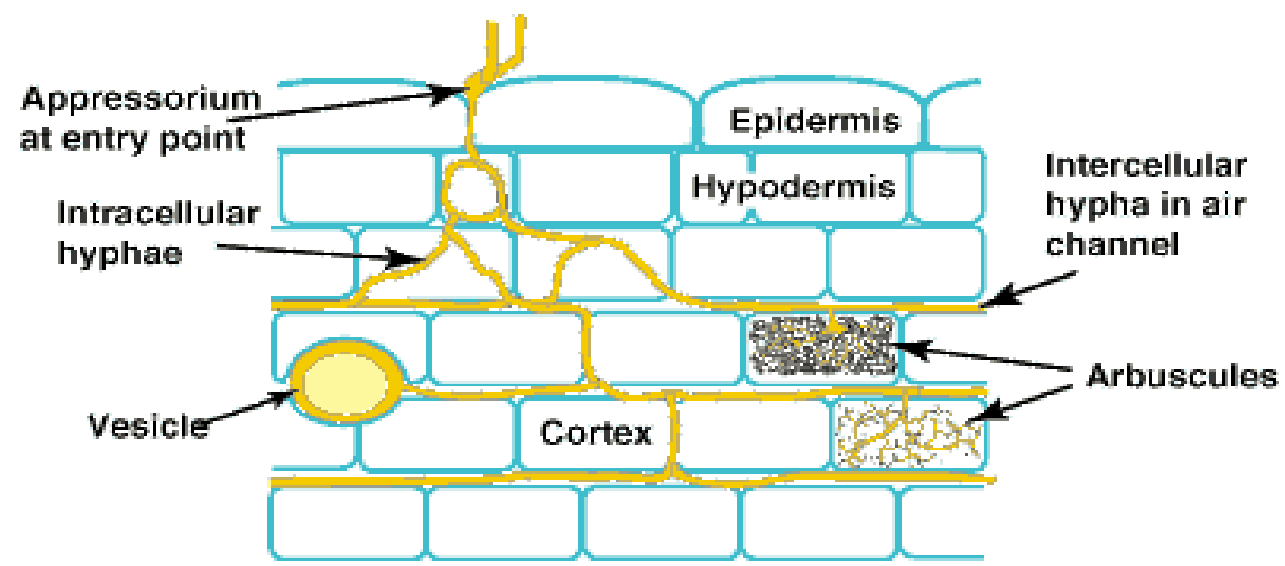

Fig.2 Arbuscular mycorrhizal fungal network in a host cell

\section{AMF inoculation in mulberry}

Rajagopal et al (1989) were probably the first to report that mulberry roots were highly colonized by AMF under natural conditions; and enhancement in phosphorus uptake leads to better leaf growth and higher biomass production in mulberry (Setua et al., 1999a; b). This triggered numerous studies on efficacy of AMF in improving mulberry plant growth and several sources of AMF inocula and methods were evaluated for successful root colonization. Thorough analysis of reports indicated that most widespread 
method followed for AMF propagation prior to inoculation is the use of trap plants $(75 \%)$ while other methods are used on limited scale (Berruti et al., 2016). Generally, three methods are employed for AMF application to mulberry plants: a) placement method b) side dressing c) planting hole. The placement method involves placing the inoculum in probable root zone of mulberry-cuttings in potting mixture just 2-3 cm below as thin layers @ 5-10\% of potting mixture; and watering it periodically. Surface coating of cuttings with AMF inoculum along with some sticking agent is another way to accomplish the task. Side dressing of established seedlings with AMF is used when the inoculum is available in insufficient quantity. In planting hole method, the inoculum is applied in planting holes (burrows) where the saplings are intended to be planted or inoculum is put near the roots of sapling. Soilbased AMF inoculum consists of either one or more species/strains of AMF like Glomus mosseae or G. fasciculatum or Acauospora sp. or Gigspora sp., etc. often used to raise mycorrhiza-infected mulberry saplings in nursery beds. The 5-6 months old mycorrhizal saplings are transplanted to the field along with nursery soil containing AMF spores. Phosphorus may be applied in these beds @ $60 \mathrm{~kg} \mathrm{ha}^{-1} \mathrm{yr}^{-1}$ instead of $120 \mathrm{~kg} \mathrm{ha}^{-1} \mathrm{yr}^{-1}$ after one year of establishment (Sakthivel et al., 2014). AMF inoculation ensures $50 \%$ curtailment of chemical phosphorus in mulberry cultivation without any loss in foliar yield and quality. The inoculation of an established mulberry garden with AMF is accomplished only after tree pruning and intercultural operations. The AMF inoculum is applied @ $1000 \mathrm{~kg} \mathrm{ha}^{-1}$ by intercropping method in furrows to a depth of $6-10 \mathrm{~cm}$ in between the mulberry rows (Katiyar et al., 1999; Rajaram et al., 2014). After AMF application, maize seeds @ $20 \mathrm{~kg} \mathrm{ha}^{-1}$ are sown in furrows at a planting distance of 5-10 $\mathrm{cm}$ for $\mathrm{AMF}$ multiplication in maize root zone. After 40-45 days growth, maize plants are cut at $20-30 \mathrm{~cm}$ height and allowed to grow for another 30-40 days. The maize plants are then cut at ground level and the soil is ploughed so that maize roots are thoroughly incorporated into soil. In such soils phosphorus is applied @ $60 \mathrm{~kg} \mathrm{ha}^{-1} \mathrm{yr}^{-1}$ instead of recommended $120 \mathrm{~kg} \mathrm{ha}^{-1} \mathrm{yr}^{-1}$ (CSRTI, 2013). Another method is applying a single dose of AMF inoculum directly in root zone of individual tree in mulberry garden in early season@1000 kg ha ${ }^{-1}$. One may also apply AMF through irrigation.

The inoculation success and perseverance of $\mathrm{AMF}$ in soil is influenced by many factors which include the species compatibility with the target environment, the degree of spatial competition with other organisms in target niche and timing of inoculation. Therefore, while taming the inoculum to a particular environment it is essential to take these factors into consideration (Berruti et al., 2019). Mulberry plants are considered to be intimately associated with AMF, so effective strains need to be identified, mass multiplied and exploited to grow mulberry advantageously. Mycorrhizal inoculants can be applied to target host in either solid or liquid form as amendments or injectables or bare root preparations. Humic acids, biostimulants, plant growth promoting rhizosphere organisms, yucca extracts and organic soil conditioners may also be added along with AMF inoculum to encourage rapid mulberry root development. Sometimes in AMF formulations the substances like HortaSorb® gels are added to lessen transplant stress, avoid water scarcity and ensure the slow release of soluble nutrients. Pentón et al (2013) found the integrated use of mineral fertilizer with AMF (through intercropping of jack-bean) as an effective method for the multiplication of AMF propagules at least up to the moderate levels. 


\section{AMF in improving plant nutrient availability}

AMF fungi under harsh conditions play key role in the survivability of seedlings, plant establishment and nutrient cycling in ecosystem. Though AMF are not host specific yet they exhibit some degree of host preference.

\section{Nutrient acquisition by AMF}

\section{Physical entanglement}

Plant root extract nutrients, especially $\mathrm{P}$, from a limited distance only up to $2 \mathrm{~mm}$ from root. Therefore, development of nutrient depletion zones in rhizosphere is a usual phenomenon. Further, most soil organic residues are solubilized or protected within soil aggregates by both physical and chemical binding mechanism. Mycorrhizae through their physical exploration scavenge and retain nutrients for a longer period. It serves as carbon sink and nutrient pool in nutrient cycling within rhizosphere. At hyphae-soil interface the newly developed depletion zones extends to several $\mathrm{mm}$ into the bulk soil (Hatfield 2018). Mycorrhizal roots under normal conditions extract nutrients beyond these depletion zones up to $15 \mathrm{~cm}$ (BattieLaclau et al., 2019). The external mycelia traverse depletion zone surrounding the root and exploit soil micro-habitats beyond nutrient depleted area where small rootlets or root hairs as such cannot thrive. In comparison, depletion zone in nonmycorrhizal plants do not extend beyond $1 \mathrm{~cm}$ from the rhizosphere. The AMF hyphae contribute $70-80 \%$ of total $\mathrm{P}$ to mycorrhizal plants (Li et al., 1991). In highly infected plants, AMF biomass may reach $10-20 \%$ of root biomass (Higo et al., 2013). The total length of external hyphae may be in the range of $1-10 \mathrm{~m} \mathrm{~cm}^{-1}$ of infected root length in AMF as compared to $1-3 \mathrm{~m} \mathrm{~cm}^{-1}$ in ectomycorrhiza and only a small proportion of external hyphae is active (Dar 2010). The root biomass of mulberry and mycorrhizal symbiosis (150 days after treatment) was higher $(490.28 \mathrm{mg}$ $50 \mathrm{~g}^{-1}$ soil and 375.33 spores in $50 \mathrm{~g}$ soil, respectively) when AMF (Glomus cubense) was inoculated through intercrop Canavalia ensiformis (Pentón et al., 2014).

Fungal biomass accounts $45-55 \%$ of total soil biomass. External hyphal composes of $26 \%$ of the extra-radical organic C pool (Miller \& Lodge 1997). Reports indicate AMF hyphae amount $12-19 \mathrm{~m} \mathrm{~g}^{-1}$ soil or $17-45 \mathrm{~m} \mathrm{~cm}^{-3}$ soil (Pfleger \& Linderman 1994). Such type of extensive physical entanglement contributes towards soil macro-aggregate formation, increase nutrient residence time within the system and minimize soil erosion losses. As a rule, in mycorrhizal plants per unit root length is 2-3 times higher than non-mycorrhizal plants (Tinker et al., 1992). Besides, the physical network links the roots of two or more plants and thus facilitates direct transfer of nutrients from one root system to another or one ecosystem to another.

\section{Cell morphological changes}

AM fungi induce morphological changes in roots in such a way that the area of physical contact between roots and soil is enhanced. This causes ten-fold increase in the absorptive root surface area. Shi et al (2016) reported that the root colonization by AMF significantly enhanced shoot height, tap root length, stem base and tap root diameter, leaf and fibrous root numbers, and shoot and root biomass production in 6 months-old mulberry plants. Although root elongation is inhibited but in all the cases the lateral root/feeder root formation is stimulated. Pan et al (2011) reported that about $82 \%$ mulberry root tips were colonized by AM fungi and transformed to mycorrhiza in various degrees. Such inoculated mulberry saplings have 
significantly better relative growth rate of root tip mass and length, and leaf area (almost $100 \%$ over control). This remarkably enhances the absorptive ability of root system and photosynthetic areas of aerial parts (Pan et al., 2011).

\section{Physiological changes}

AM fungi efficiently regulate the normal growth, metabolism and physiological activity of mulberry plants. Mycorrhizal plants compensate the plant's higher demand of photosynthates by enhancing their rate of photosynthesis per unit leaf area. More than $50 \%$ forest and herbaceous photosynthates are directed to the belowground parts to support root mycorrhizae and associated microbes, and half of it is usually respired (Johnson et al., 2002). About 4-14\% carbon photosynthesized by plant is utilized by symbionts alone (Paul \& Clark 1991). In turnover of fine roots, fungal components contribute about $50 \%$ of total turnover (Dar 2010). Close association of fine fungal structures, especially the developed plasmalemma of plant cell serve as sites for nutrient transfer. AMF and fine coiled hyphae have a turnover time of 4-15 days (Willis et al., 2013). The cell volume increases and the weight of plant cytoplasm within a mycorrhizal plant cell enhances about 20 times than that of uninfected one (Tate 2004).

Mulberry plants respond variably to different AMF species (Setua et al., 2009). Shi et al (2016) in a comparative study on functional distinctions of three AMF species (Acaulospora scrobiculata, Funneliformis mosseae and Rhizophagus intraradices) found that mulberry biomass production and nutritional quality is AMF-species dependent. Reddy et al (1998) and Shi et al (2016) reported that AMF colonization favourably affected physiological characteristics like leaf chlorophyll a or b, total chlorophyll and carotenoid contents, net photosynthetic rate, transpiration rate and stomatal conductance in mulberry as compared to their uninoculated counterparts; however, the intercellular $\mathrm{CO}_{2}$ concentration was significantly low. Shi et al (2016) noticed that mycorrhization significantly improved leaf moisture, total nitrogen, essential amino acids (like histidine, proline), soluble protein, sugars and fatty acids. The effectiveness of AMF was in order: $F$. mosseae $>A$. scrobiculata $>R$. intraradices for physiological and growth parameters; and $F$. mosseae $\approx A$. scrobiculata $>R$. intraradices for leaf quality. The increase in photosynthetic pigments appears due to the compatible synergism between transpiration and photosynthesis under mycorrhization (Chen et al., 2016). The greater stomatal conductance of mycorrhizal plants implied a lower leaf resistance to moisture diffusion which ultimately leads to faster water transportation. Mycorrhizae also influence stomatal regulation (Shi et al., 2016). Kumaresan et al (2011) reported that mulberry plants (cv. MR2 and Kanva2) inoculated with Glomus aggregatum and $G$. fasciculatum had high contents of reducing and total sugars, total proteins, amino acids, lipids, phenols, acid and alkaline phosphatases, etc. as compared to their single inoculations.

\section{Overcoming the persistent phosphorus limitation in soil}

Phosphorus plays a major role in balanced supply of nutrients to the plants. Only watersoluble phosphorus is useful for crop plants. In soils, only $0.1 \%$ of total $\mathrm{P}$ is available as it is sparingly soluble, least mobile and shows very limited diffusion in soil (Dar 2010). The rest $\mathrm{P}$ remains fixed in clay lattice, organic matter, etc. Generally, $\leq 15 \%$ of applied fertilizer P is used by crops. About $50-67 \%$ of total $\mathrm{P}$ supply is organically bound and cannot be utilized by plants without solubilization. 
Mycorrhizae through their enzymatic activity viz., acid phosphatases, esterases, etc. solubilize and degrade organic phosphorus into orthrophosphates and scavenge them as polyphosphates. Acid phosphatase is an ectoenzyme and its activity is high all along the external mycelium-root interface. The polyphosphates are sequestered within fungal vacuoles and accumulated in plant roots even when plants are under severe P-limited conditions. AMF absorb nutrients, particularly $\mathrm{P}$, from soil so significantly contributes to nutrient cycling in ecosystem (Katiyar et al., 1995). Mycorrhiza through proliferation and entanglement via fibrous hypha into soil and engulf every tiny soil crevice to absorb water and nutrients, thereby provide soluble nutrients to plant roots. The phosphates are then transferred from hyphae to cytoplasm. The fungal hyphae have greater affinity for phosphorus than host roots. About $80-90 \%$ of the absorbed phosphates remain accumulated in fungal hyphae (Rao 2016). Further, organic phosphates like phytate in soil are easily decomposed by mycorrhizal fungi. Nutrient cycling activities like organic matter decomposition, mineralization and elemental fixation are enhanced through boosting the growth of beneficial microbes in mycorrhizosphere.

The required minimum concentration of phosphorus in soil solution for uptake by roots is $>0.1 \mathrm{ppm}$. In contrast, AMF mobilize phosphorus uptake at extremely low $\mathrm{P}$ concentration of $<0.001 \mathrm{ppm}$ in soil (Hekstra 1996). A concentration gradient is formed in such case resulting in the dissolution of phosphorus. The mechanism of nutrient uptake is greatly enhanced by the soil volume explored by fungus. AMF hyphal network provides about 10-fold absorption surface than that of the root system of uninfected plant. This enhances plant root efficiency as well as nutrient uptake efficiency per unit surface area through improved proton- extrusion mechanism and organic acid (like oxalate, acetate, fumerate, etc.) production (Quoreshi 2008). The production of organic acids solubilizes $\mathrm{Fe}, \mathrm{Al}$ and $\mathrm{P}$ in soil and precipitates them with $\mathrm{Ca}$, thereby accelerates their mobility, and improves mineral weathering and mineralization process. The acid production (formic, acetic, oxalic, etc.) by AMF lowers soil $\mathrm{pH}$, and the acidification created enhances the mobility of Ca-bound phosphates and elevates $\mathrm{CO}_{2}$ production by roots.

\section{Sustained nutrient supply}

The inoculation of mulberry with AMF not only improves soil $\mathrm{P}$ uptake but also enhances soil nitrogen extraction capacity of plant and ensures sustained supply of other nutrients in a manner that favourably influences plant growth and physiological performance, depending upon the AMF species used (Pentón et al., 2014). Ambika et al (1994) found no significant correlation between AMF colonization and growth and yield of mulberry but in some mulberry genotypes the uptake of leaf nitrogen and phosphorus was influenced by natural AMF association. Mycorrhizal association beside $\mathrm{P}$ and $\mathrm{N}$, also enhances $\mathrm{N}, \mathrm{K}, \mathrm{S}, \mathrm{Fe}, \mathrm{Mn}, \mathrm{Zn}, \mathrm{Mg}, \mathrm{Ca}$ uptake from soil (Evelin et al., 2009). The uptake of $\mathrm{NH}_{4}{ }^{+}$is facilitated by mycorrhizae in forest trees (Piao \& Wang 2016). $\mathrm{Zn}$ and $\mathrm{Cu}$ uptake is increased under deficient conditions. In contrast, Mn is often much low in AMF plants probably due to the AMF-induced changes in rhizosphere microorganisms in general and Mn-reducers in particular vis-a-vis increase in Mn oxidizers (Nogueira et al., 2004). Low Ca content in mycorrhizal plants is probably related to the changes in root morphology and differentiation (Cardoso Filha et al., 2017). AMF contributes to improvement in soil organic matter and $\mathrm{K}$ content (Pentón et al., 2013). Padma \& Sukumar (2015) reported a significant increase in mulberry plant growth 
and leaf fresh biomass when $G$. mosseae was applied along with phosphorus solubilizing and biological nitrogen fixing bacteria. Coinoculation of AMF with such beneficial bacteria favourable influenced macronutrient uptake through leaf with maximum nitrogen (484.12 kg ha ${ }^{-1}$ ), phosphorus (59.83 kg ha ${ }^{-1}$ ) and potassium (244.61 kg ha ${ }^{-1}$ ) uptake in coinoculation treatments as compared to the uninoculated ones (Baqual \& Das 2006).

\section{Release of growth promoting hormones}

The mycorrhizal associations induce the growth and activities of plant growth promoting rhizo-organisms, thus accelerate organic matter decomposition, mineralization processes and other soil enzyme activities (Giovannini et al., 2020). They enhance siderophore production, accelerate iron chelation and increase its bioavailability to plants. In addition, many mycorrhizae synthesize phytohormones such as auxins, indole acetic acid, ethylene, gibberellins and cytokinins that induce feeder root proliferation (Egamberdieva et al., 2017). Lateral and feeder root formation is stimulated by fungal auxins. Higher cytokinin synthesis has been observed in AMF inoculated plants which has been attributed to the increase in photosynthetic activity, higher transpiration, greater $\mathrm{P}$ uptake, efficient $\mathrm{Fe}$ transfer and better nutrient acquisition (Evelin et al., 2019; Begum et al., 2019). Hormone production is accelerated in root zone due to the boosting of beneficial microbes in mycorrhizosphere. AMF enhance photosynthesis rate vis-à-vis alter the partitioning of photosynthates (carbohydrates) between shoot and root thereby increase the flow of carbohydrates to roots. These physiological alterations coupled with improved mineral uptake enhance the nutrient status of host tissue ( $\mathrm{Lu}$ et al., 2015). Moreover, there is change in cell membrane permeability as well as the quality and quantity of root exudates improve. The qualitative and quantitative change in soil microbial biomass and organic matter decomposition in mycorrhizosphere favours greater nutrient mineralization in soil. The extra-radical hypha increases the potential of root system for better nutrient and water absorption and selective ion uptake and accumulation (Begum et al., 2019).

\section{Improvement in soil microbial function}

Rhizosphere generally experiences greater rates of mineral weathering than bulk soil. In arable soils the mass of roots left after crop harvest is usually $15-40 \%$ to that of the above-ground crop which weighs 25 to $85 \mathrm{t}$ $\mathrm{ha}^{-1}$ (Brady \& Weil 1996). This alters rhizosphere flora and subsequent successions. These organisms become a component of plant rhizosphere and occasionally invade the internal parts of root, where these promote root hair development and branching. Some associated helper organisms with AMF fix atmospheric nitrogen in roots of mulberry and produces plant growth hormones. Litter decomposition seems to be the main source of nutrients supply to mulberry plant by means of microbial processes in soil and the environmental factors along with some basic characteristics of host plant play a dominant role in distribution of these microbes (Saima 2017). She found highest AMF population in mulberry fields in spring season and lowest in summer season. To improve nutrient availability and microbial activity, the use of lime in acidic soil, and gypsum and green manuring in saline and alkaline soil are recommended to bring soil reaction in optimal range [pH 6.3-7.2] (Thimmareddy et al., 1999).

It is well established that the symbiosis between soil fungi and plant roots play a key role in plant productivity. AM fungi extend the effective root length by 100 -fold or more 
by spreading the mycorrhizal network through Hartig's net (Saima 2017). AMF not only increase the root surface area for nutrients and water extraction but also penetrate tiny pores that roots as such can't penetrate, thereby protect plants from mild drought stress and help to deter the activity of root pathogens (Dar et al., 2010). AMF symbiosis is generally characterized by rapid and frequent colonization of new roots and the appearance of vesicles in the oldest colonizing units. Setua et al., (2001) observed a maximum root colonization of $72 \%$, arbuscule $17 \%$, vesicle $19 \%$ and arbuscule with vesicle formation $(50 \%)$ in six high yielding mulberry cultivars in Kashipur, West Bengal (India). They observed highest population of spores (13 spores $\mathrm{g}^{-1}$ rhizosphere soil) at low moisture levels during summer followed by winter season. Studies on roots and rhizosphere soil of 25 mulberry genotypes for indigenous AMF colonization in Mysore, Karnataka (India) revealed that 5 genera of AMF (Glomus, Acaulospora, Sclerocystis, Gigaspora and Scutellospora) were present in rhizosphere soil of different genotypes. Glomus is the most predominant species associated with mulberry (Ambika et al., 1994). Xing et al., (2018) using molecular analysis and genetic sequencing found eight known genera and distinct 83 species of AMF in soil and mulberry root samples collected from Libo (China) in soil with genera Glomus, Paraglomus, Archaeospora and Diversispora as dominant species. However, the root samples taken from Bijie (China) had relative abundance of Glomus, Paraglomus, Acaulospora and Claroideoglomus species revealing that the soils vary in their AMF diversity. Fathima et al (2000) reported that mulberry saplings inoculated with $G$. fasciculatum with P applied @ $30 \mathrm{~kg} \mathrm{ha}^{-1} \mathrm{yr}^{-1}$ in the form of diammonium phosphate had highest root colonization while in case of $G$. mosseae-inoculated saplings, root colonization was highest with similar treatment but $\mathrm{P}$ applied in the form of Mussoorie rock phosphate. Further, the spore load in mulberry rhizosphere was significantly higher with $\mathrm{P}$ applied at $30 \mathrm{~kg}$ $\mathrm{ha}^{-1} \mathrm{yr}^{-1}$ as Mussoorie rock phosphate than with recommended $\mathrm{P}$ i.e. $120 \mathrm{~kg} \mathrm{ha}^{-1} \mathrm{yr}^{-1}$ as SSP. A significantly higher root colonization of $\mathrm{AMF}$ and reduced requirement of $\mathrm{N}$ and $\mathrm{P}$ fertilizers is an indication of better association of AMF in the rhizosphere of mulberry (Reddy et al., 1998).

Many microbes in conjunction with AMF render nutrients available to the plant in easy manner. Of these, Azospirillum and Azotobacter as nitrogen fixers, and AMF and phosphorus solubilizing bacteria (PSB) as phosphorus biofertilizers have a vital role in supplying nutrition to mulberry (Baqual et al., 2017; Todeschini et al., 2018). Combined inoculation of $\mathrm{N}_{2}$-fixing organism Azospirillum or Azotobacter and AMF increased plant height and shoot and leaf biomass of mulberry (Baqual \& Das 2006; Shi et al., 2016). The synergistic actions like continuous release of growth promoting substance by Azospirillum or Azotobacter from root surface into rhizosphere, photosynthate supply to Azospirillum/ Azotobacter and AMF by host plant, and nutrient and water exploration by AMF trigger a cascade of events leading to better plant health. Mycorrhizal colonization enhances the population of Azospirillum chroococcum in rhizosphere and maintains it at a high level for a longer period of time (Mohamed \& Massoud 2017). The beneficial effect of free-living nitrogen fixing organisms on plant growth is mainly due to hormone production, in addition to nitrogen fixation (Singh 1998). Phosphate solubilizing bacteria (PSB) survive for longer period in rhizosphere of mycorrhizal roots with PSB rendering more phosphorus soluble and AMF enhancing its uptake (Ordoñez et al., 2016, Wahid et al., 2016, Baqual et al., 2017). Field 
trials conducted to study effect of Glomus mosseae, $\mathrm{N}_{2}$ fixing Azotobacter chroococcum and a commercially available PSB inoculant (Biophos) on mulberry saplings in nursery have revealed that combined inoculation with all three inoculants enhanced biomass and $\mathrm{P}$ yields (Mary 2012). Integrated use of biofertilizers and chemical fertilizers is desired to ensure the sustained productivity in mulberry. The scope for utilizing these organisms to improve the growth and vigour in commercial mulberry nursery are enormous (Padma et al., 1999).

\section{Mulberry survival and growth}

Mycorrhizae improve plant survival, growth and development, nutrient cycling, feeder root health, longevity and tolerance to abiotic stresses like drought, soil toxins, extremes of $\mathrm{pH}$, temperature, etc. Soil deterioration is also minimized through improvement in soil structure, aggregation, aeration, $\mathrm{pH}$, microbial biota, etc. The net effect of these changes is a healthier plant, capable to withstand adverse environments. The impact of various AMF inocula on mulberry plant growth and survival is given in Table 1. Fathima et al (2000) found that the inoculation of mulberry with $G$. fasciculatum and $G$. mosseae + annual application of $30 \mathrm{~kg} \mathrm{P} \mathrm{ha}{ }^{-1}$ gave similar yields to the control (full dose of chemical fertilizers). Inoculation with AMF thus allows a considerable decrease in phosphorus fertilizer use in mulberry cultivation (CSRTI, 1992). Mamatha et al (2002) found both the growth and foliar yield of 10-year-old mulberry plants (cv. M5) were similar in treatments of $100 \% \mathrm{P}$ fertilizations and $50 \% \mathrm{P}+$ Funneliformis mosseae or $G$. fasciculatum inoculation. A comparative study on AMF inoculation and phosphorus application on the growth and development of mulberry saplings cv. 'S13' under semi-arid conditions revealed better plant survival, improvement in growth attributes and major nutrients and higher AMF root colonization. AMF inoculated saplings were superior in growth and development than the saplings grown in nursery beds with and/or without phosphorus (Baqual et al., 2005).

Bharadwaj \& Sharma (2006) reported a net saving of $25 \%$ of recommended dose of inorganic $\mathrm{P}$ in mulberry with the use of AMF in alkaline soils. Ram Rao et al (2007) and Kaur et al (2009) achieved 50\% reduction in chemical $\mathrm{P}$ fertilizers use when AMF were used and the treatments did not affect the leaf quality traits or cocoon parameters. In mulberry, only a few reports are available with regard to the use of AMF and those point towards the effectiveness of such inoculations in curtailing the recommended dose of chemical fertilizers (Umakanth \& Bagyaraj 1998; Reddy et al., 2000; Kashyap et al., 2004). Mulberry var. tigriada inoculated with AMF EcoMic® strain Glomus cubense revealed highest nutrient extractions in rainy season and in the treatment involving integrated use of AMF and fertilization which reduced $50 \%$ chemical fertilizer dose (Pentón et al., 2014).

AMF remarkably enhances the absorptive ability of root system, promotes vegetative growth, improves photosynthetic capacity and prolongs mulberry survival rate under harsh agro-climatic conditions like desert area (Chen et al., 2014). Inoculation of Funneliformis mosseae and Rhizophagus intraradices enhanced leaf number, plant height, chlorophyll, $\mathrm{N}$ and $\mathrm{P}$, root and aboveground biomass production in 90-dayold mulberry seedlings (Lu et al., 2015). The combined application of mycorrhizal fungi and other beneficial microbes could promote the growth of mulberry. For instance, the coinoculation of two AMF species (Glomus fasciculatum and $F$. mosseae) with other beneficial microbes (Azotobacter sp., Bacillus megaterium and Aspergillus awamori) 
enhanced macro- and micro-nutrient uptake and improved foliar chlorophyll content in mulberry (Baqual \& Das 2006; Lu et al., 2015). Besides, such combined/ dual inoculations (F. mosseae + Azotobacter chrococcum) improved mulberry foliar quality and cocoon characters (Ram Rao et al., 2007).

Scanty information is available on the influence of various AMF species (inter- and intra-genus) on the quantity and quality of mulberry foliage which, in turn, directly affects the silkworm health, cocoon production and silk product quality. The nitrogen, protein and amino acids, especially methionine, histidine and threonine, concentration in mulberry leaf strongly influence the quantity and quality of cocoon shell (Ram Rao et al., 2007). For instance, methionine and histidine are essential for the growth of silkworms; and threonine is crucial for the synthesis of silk protein (Machii \& Katagiri 1991). Similarly, brilliant colour of cocoons is mainly dependent on carotenoid concentration in mulberry leaves (Tabunoki et al., 2004). Significantly higher effective rate of rearing $(95.3 \%)$, single cocoon weight $(2.1$ $\mathrm{g})$, single shell weight $(0.44 \mathrm{~g})$, maximum filament length $(936 \mathrm{~m})$ cocoon $^{-1}$ and reel ability $(86 \%)$ were observed by feeding silkworm the mulberry leaves harvested from the trees co-inoculated with AMF and beneficial micro-organisms and supplemented with $175 \mathrm{~kg} \mathrm{~N}$ and $70 \mathrm{~kg} \mathrm{P} \mathrm{ha}{ }^{-1} \mathrm{yr}^{-1}$ with $\mathrm{P}$ applied in the form of rock phosphate (Baqual \& Das 2006). Ram Rao et al (2007) achieved $50 \%$ reduction in chemical $\mathrm{P}$ fertilizers use when AMF were used and the treatments did not affect the leaf quality traits or cocoon parameters.

Song-mei (2016) revealed higher AMF diversity including those of Acaulospra scrobiculata, Funneliformis mosseae and Rhizophagus intraradices in field-grown mulberry. Such diversity of AMF provide long term qualitative and quantitative gains to mulberry and soil (Pan et al., 2011; Shi et al., 2013). Chen et al., (2014) reported > 50\% root colonization in mulberry seedlings, significantly highest with $F$. mosseae and least with $R$. intraradices. Further, they observed significant enhancement in leaf net photosynthate rate (by 52-99\%), stomatal conductance (by 24-56\%) and transpiration rate (by 66-104\%), and decrease in intercellular $\mathrm{CO}_{2}$ concentration (by $5-15 \%$ ) in AMF colonized plants as compared to uninoculated ones.

\section{Role in overcoming biotic and abiotic stress}

Excessive and exclusive dependence on chemicals to combat pests and diseases has destabilized the ecological balance and threatened the stability of ecosystems. This has also led to the development of pesticide resistance in pests and pathogens, destruction of beneficial soil microbes and accumulation of pesticide residues in food and water culminating in chromosomal aberrations in humans and animals leading to several genetic disorders. Biocontrol agents including mycorrhiza are a boon to mankind. The bioagents developed are the microbial products which fight the diseases/pests and help in developing sound ecofriendly sustainable environment (Pozo \& AzcónAguilar 2007; Baby Summuna et al., 2019). The use of biological agents can replace or at least minimize the use of synthetic biocides, which are harmful to silkworms as well as to the soil microflora and fauna of mulberry rhizosphere (Bhat et al., 2018). The mycorrhizae used in several formulations have specialty of very high saprophytic colonizing ability thus through competition for space and nutrient and their scavenging abilities, cell modification and antimicrobial compound production help in inducing tolerance/resistance to mulberry against root- 
and soil-borne diseases (Tahat et al., 2010). The application of microbial inoculants especially AMF influences the resident microbial communities and offer protection against a wide spectrum of pathogens (Jambhulkar et al., 2016). These also produce growth promoting substances which help in plant growth and improve soil health and productivity.

Diseases cause 5 to $10 \%$ loss in mulberry leaf yield and additional loss of 20 to $25 \%$ by deterioration in leaf quality (Sukumar \& Padma 1999). Vegetative propagation of mulberry is adversely influenced by root- and soil-borne pathogens especially those causing root rot (Beevi \& Qadri 2010). Stem canker (Botryodiplodia theobromae), powdery mildew (Phyllactinia corylea) cutting rot (Fusarium solani, F. oxysporum), root rot (Rhizoctonia bataticola) are the major diseases which incite high mortality of stemcuttings, thus affect the early survival and establishment of mulberry (Vijaya Kumari 2014). Apart from diseases, the poor rooting ability of stem-cuttings of many promising mulberry varieties leads to unproductive propagation. The inoculation of mulberry with $G$. mosseae or $G$. fasciculatum in combination with 6-90 $\mathrm{kg} \mathrm{P} \mathrm{ha}^{-1} \mathrm{yr}^{-1}$ reduced the incidence of bacterial blight caused by $P$. syringae pv. mori (Sharma et al., 1995). Integrated use of AMF and Verticillium clamidosporwm effectively controlled root rot nematode (Meloidogyne incognita) problem up to $83.3 \%$. (Kumari and Sujathamma 2011). The population of insect pests like white fly and thrips were significantly reduced below the economic threshold level in experimental plots treated with organic manures and biofertilizers including AMF over control (Chakraborty et al., 2015).

Mycorrhizal association supports the host plant in overcoming the various abiotic stresses like water scarcity, drought, extreme soil and weather conditions, heavy metal, etc. (Schutzendubel \& Polle 2002, Göhre \& Paszkowski 2006; Trouvelot et al., 2015; Wu 2017; Chen et al., 2018). AMF treated seedling successfully withstand drought conditions than non-mycorrhizal seedling (Augé 2001). Mycorrhizal association also influences plant water relations directly or indirectly (Augé 2004). Rhizomorph or extended extra-radical mycelium increase the transport of water to the host (Finlay 2008). Evidences reveal that ectomycorrhizal fungi can grow better in solutions of higher osmotic stress than that which may plasmolyze nonmycorrhizal root hairs (Liu et al., 2018). Mycorrhizae belonging to Basidiomycotina class appear tolerant to water stress up to the extent of -70 bars (-7 MPa) (Harris 1980). Growth rate or colonization potential is, however, substantially reduced at much lower water potential (Ruiz-Lozano et al., 1995). It is argued that AMF infections strongly increase water transport from soil to host plant leaves owing to the presence of large number of hyphal entry points on roots, greater hyphal length, better surface area linking of host roots with other plants, large exploration of soil and greater resistance/ protection offered by the fungus against natural vagaries (Berruti et al., 2016). It has been estimated that a hyphal diameter of $5 \mu \mathrm{m}$ and a root diameter of $500 \mu \mathrm{m}$ leads to $1 \mathrm{~m}$ of hyphal length, having surface area equivalent to $1 \mathrm{~cm}$ of root length. Exploitation of water reserviours is accomplished beyond the root zone by mycorrhizal hyphal network (Dar 2010). Further, stomatal regulation is another way of AMF seedling possessing drought tolerance (Begum et al., 2019). Stomatal regulation is known to be stimulated by increased cytokinin level in plants. Mycorrhizal plants possess higher concentration of sterols which influence membrane permeability (Dar 2010). Further, the ability of mycorrhizae to conserve soil and water enhances the ability of mulberry plants 
to tolerate biotic and abiotic stresses (Tahat et al., 2010; Abbasi et al., 2015).

The improvement in nutritional status in plants due to AMF colonization contributes to the enhancement in plant biomass (Treseder 2013; Taylor et al., 2014), resistances to root diseases (Al-Askar \& Rashad 2010), salt tolerance (Kashyap et al., 2004) and drought tolerance (Tang et al., 2013). Moreover, extended root system by mycorrhization greatly enhances the absorption surface thereby accelerates higher nutrient uptake (Lambers et al., 2006; Shi et al., 2016). For successful mulberry raising, both acclimatized AMF species and appropriate cultivation management practices should be considered. In mulberry AMF association leads to higher leaf chlorophyll content which improves photosynthetic rate, carbon fixation and carbohydrate accumulation. AMF colonization also enhanced significantly higher carotenoid accumulations, leading to better leaf nutraceutical values of mulberry plants (Lambers et al., 2006).

The toxicity of heavy metals such as $\mathrm{Zn}, \mathrm{Pb}$, $\mathrm{Ni}, \mathrm{Cd}, \mathrm{Cr}, \mathrm{Cu}$, etc. is greatly reduced in AMF infected plants (Galli et al., 1994), through their sequestration either in fungal structures or extra-metrical mycelium in the sheath (Gonzalez-Guerrero et al., 2008). The heavy metals are bound by carboxylic group present in pectic substances (hemicelluloses) of interfacial matrices between fungus and host cell (Dar 2010). Copper, for example, can become available at phytotoxic concentrations in mine spoils but the fungal tissues that form mycorrhizal association with root system exclude copper under these situations by complexing the metal (Zhang et al., 2009). Mycorrhizae in plants are reported to offer resistance against salinity as well besides overcoming the harsh environmental conditions in soil, if any (Porcel et al., 2012; Evelin et al., 2019).

\section{Soil and water conservation}

The contribution of extra-radical hypha of AMF to the process of creating a stable soil aggregate structure is much overlooked subject. AMF hyphae along with other saprophytic fungi and fibrous roots bind soil particles and convert micro-aggregates into macro-aggregates through physical entanglement and secretion of polysaccharides and other organic compounds (Lehmann et al., 2017). The mechanical entanglement by hyphae physically brings mineral particles and soil debris together and form more stable macro-aggregates through cementation by their secretions (Miller \& Jastrow 1992; Wilson et al., 2009). This allows improved soil aeration and water percolation as well as accelerates soil biological activities. Eroded soils contain less mycorrhizal propagules so need supplementation of appropriate eco-specific AMF species (Vogelsang et al., 2004).

On an average mulberry plants require 3.22 lakh litres of water per ha once every 10 days in case of loamy soil and 15 days in clayey soils (Sarkar et al., 2000). So mycorrhizal colonization has vital role in imparting drought resistance and tolerance towards abiotic stress, especially in mulberry, thus helping in their survival under adverse conditions and restrict soil exposure to water and wind erosion. Conservation of nutrients within various ecosystems is also enhanced by the formation of various semi-permanent mycelial system which form absorptive networks, inter-linking plants both at intraand inter-specie level (Table 2). Understanding how nutrient absorption processes in plants are related to arbuscular mycorrhizal association is critical for predicting the effects of AMF symbiosis on elemental cycling for plants (Piao et al., 2016). 
In forest ecosystem, 3 to 5 times more organic matter is returned to soil in the form of root and mycorrhizae than is returned by the decomposition of litter (Fogel 1988). Of this, mycorrhizae account $85-95 \%$ and the rest is from soluble root exudations, root caps and mucilages (Dar 2010). The higher input in mycorrhizal plants of organic carbon into the soil has vital consequence on the number, activity and distribution of soil microorganisms. It alters soil-root interface as well as the quality of rhizosphere organisms and their composition and activity so forming a new 'mycorrhizosphere' (Azcón-Aguilar Barea 2015; Gupta \& Aggarwal 2018). Mycorrhiza influence vegetation pattern within the community through extra-radical hyphal bridge between individual plants of the same or different plant species in a mixed stand. Such transfer, for example, is possible for $\mathrm{N}$ nutrient between root system of legumes and non-legumes in a mixed stand or in intercrop with mulberry and other plants (Li et al., 2016). Intercropping alfalfa significantly improved soil physicochemical properties and rhizosphere soil fungal community including AMF diversity in mulberry (Zhang et al., 2019). Therefore, it is essential to have better understanding of soil fungal communities while exploring their influence on any cropping or agroforestry system. Such information would help in realizing the fungi-mediated effects of agricultural practices on the processes of soil nutrient cycling and crop productivity (Saranya et al., 2011).

In forest system nutrients transfer from one root system of one plant to another is accomplished through mycorrhizal links. Zeng et al (2019) reported that ShanonWierner indices for bacteria and AMF improved by 13.6-17.7 and 20.0-36.9\%, respectively, under tree-herb intercrop situations. Interplant transfer, for AMF systems has been demonstrated and it is suggested that these mycorrhizal pathways facilitate nutrient conservation at ecosystem level (Read et al., 1985). Mycorrhizal associations appear to influence community structure via mutualistic and competitive processes; whereas at ecosystem level, the mycorrhizal functioning/processes and composition may shift depending upon mycorrhizal vegetative pattern within the community (e.g. succession) [Zargar et al., 2000]. Temporal succession of fungal species is associated with aging of a plant (Shi et al, 2016; Dighton \& White 2017) which is also appliable to mulberry plant. In undisturbed ecosystem, 'early colonizers' in tree plants are succeeded by 'late colonizers' with the passage of time. Such succession occurs due to the changes in resource quality and because of selection pressure. Late stage colonizers exhibit well-developed proteolytic potential. There are some indications that diversity of mycorrhizal species declines from natural ecosystem to intensive agricultural system. The diversity and structure of fungal community are predominantly influenced by planting pattern and soil environmental factors. Variance partitioning analysis have revealed that planting pattern explain $25.9 \%$ variation of fungal community structure, while soil environmental factors explain $63.1 \%$ variation (Zhang et al., 2019). Hence, it is deduced that the combined action of planting pattern and soil physicochemical properties alter the soil fungal community structure. Seasonal variation influences mulberry root colonization and AMF abundance. Supriya \& Purshotam (2012) reported that mulberry roots are heavily colonized by AMF and exhibit maximum AMF spore abundance during active growth period (i.e. spring) and least in summer. Such variations may be ascribed to the factors like soil nutrient status, organic matter content, climatic conditions (soil moisture, temperature), AMF strains, soil $\mathrm{pH}$, host cultivar, etc. It appears that increased AMF 
population during active growth is due to the accumulation of high energy substrates in the preceding growing season (i.e. winter). However, there is a declining trend in AMF population with increase in altitude or in other words, the AMF richness and biodiversity decrease with increase in geographical altitude (Birhane et al., 2017).

\section{Thrust areas}

Mulberry is a typical arbuscular mycorrhizal plant, so the use of efficient AMF has great significance in overcoming the limitation of poor habitat for this less preferred crop in view of lesser remuneration compared to other horticultural and forest crops. Some of the approaches to be followed must focus on:

Development of mycorrhizal technologies leading to the enhanced functioning.

Difficulties in morphological characterization of AMF may be overcome by generating a sound biochemical and molecular phylogenetic database. So reliable molecular markers/probes and primary genetic database is desired for detection and accurate identification of AMF in field.

Little is known about the composition and diversity of AMF communities in root systems of mulberry at different stages of growth under varied edaphoclimatic conditions which need to be explored.

The impact of variations in soil environment both at micro- and macro-levels and the changes in diversity of AMF communities in fragile ecosystems has received meagre attention. Site disturbances by anthropogenic activities influence AMF diversity and function, despite the fact that they have great potential in restoring the disturbed areas and low fertility soils (Bhale et al., 2018). It is, therefore, vital to assess the impact of site disturbance on diversity and structure of AMF communities. Recovery of AMF after disturbances viz-a-viz ecosystem stabilization potential of mycorrhizal-mulberry in adverse situations need to be evaluated.

Clear understanding of the impact of environmental changes, especially as a result of global warming, on AMF diversity and stability is required.

For sustainable mulberry raising, the restoration of natural level of AMF richness can provide an effective alternative to conventional fertilization practices. For this purpose, the re-introduction of AMF propagules into a target soil and taming AMF to that environment can be an effective strategy.

Field-oriented studies are required to fully exploit AMF especially with respect to their stress mitigative and disease control effects for long term benefits to mulberry.

The bulk production of AMF crude inoculum remains a very challenging arena though many new methods for mass production and seed coating technology have been developed (Ijdo et al., 2011; Vosátka et al., 2013). Since different plants vary their response to the same AMF species mix, therefore, species-specific strains as well as microbial consortia having effective AMF as a component need to be developed to achieve long term benefits of microbial inoculation. 
Table.1 Impact of mycorrhizal inoculation on mulberry (\% increase over control)

\begin{tabular}{|l|c|c|c|c|c|}
\hline Parameters & $\begin{array}{c}\text { Glomus } \\
\text { mossae }\end{array}$ & G. fasciculatum & G. estunicatum & $\begin{array}{c}\text { Gigaspora } \\
\text { Sp. }\end{array}$ & $\begin{array}{c}\text { Acaulospora } \\
\text { sp. }\end{array}$ \\
\hline Survivability & 12.9 & - & - & - & - \\
\hline Plant height & 50.8 & - & - & - & - \\
\hline Shoot dry weight & $64.7-162.3$ & 90.7 & 44.7 & 56.7 & $\mathbf{3 6 . 7}$ \\
\hline Leaf number & 25.0 & - & - & - & - \\
\hline Leaf fresh weight & 120.0 & - & - & - & - \\
\hline Leaf dry weight & $76.7-107.0$ & 93.8 & 44.6 & 58.5 & $\mathbf{4 3 . 8}$ \\
\hline Leaf moisture & 2.2 & - & - & - & - \\
\hline Chlorophyll content & 46.2 & 85.8 & 39.6 & 42.5 & $\mathbf{2 1 . 3}$ \\
\hline Total carbohydrates & 35.3 & 56.7 & 23.2 & 37.9 & $\mathbf{1 4 . 6}$ \\
\hline Reducing sugars & 30.5 & 49.2 & 14.1 & 22.1 & $\mathbf{1 3 . 3}$ \\
\hline Root colonization & $\mathbf{5 6 . 2}$ & - & - & - & - \\
\hline S & & & & & \\
\hline
\end{tabular}

Source: Das et al., (1995); Kumutha (2001)

Table.2 Multifaceted role of arbuscular mycorrhizal fungi in mulberry ecosystem

\begin{tabular}{|c|c|c|}
\hline \multicolumn{2}{|l|}{ Ecological aspects } & Processes and phenomenon \\
\hline \multicolumn{3}{|l|}{ Micro-level } \\
\hline \multirow[t]{2}{*}{ - Roots } & Soil & $\begin{array}{l}\text { Soil micro- and macro-aggregate formation, } \\
\text { Nutrient mobilization and uptake, } \\
\text { Organic acid \& enzyme production, } \\
\text { Hyphal exploration beyond nutrient depletion zones, } \\
\text { D Improvement in soil physicochemical conditions } \\
\text { Dycorrhizosphere development }\end{array}$ \\
\hline & Plant & $\begin{array}{l}\text { Plant survival and establishment, } \\
\text { Root morpho-physio-biochemical changes, } \\
\text { Plant nutrient and water absorption and uptake, } \\
\text { - Growth hormone production, } \\
\text { Quality and yield improvement, } \\
\text { Pest and disease tolerance and resistance, } \\
\text { P Tolerance to abiotic stresses like heat/water stress }\end{array}$ \\
\hline \multicolumn{3}{|r|}{ 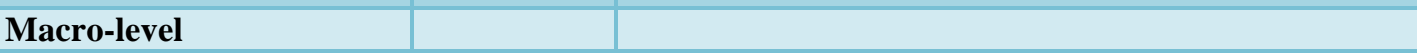 } \\
\hline - Community & & $\begin{array}{l}\text { Structural and functional diversity } \\
\text { Mutualistic and competitive associations } \\
\text { Intra- and intra-species linkage } \\
>\text { Habitat restoration }\end{array}$ \\
\hline - Ecosystem & & $\begin{array}{l}\text { Nutrient retention and conservation, } \\
\text { Soil and water conservation against erosion, } \\
\text { Ecosystem stability and restoration, } \\
\text { Organic matter recycling }\end{array}$ \\
\hline
\end{tabular}

AMF can play a major role in quest for sustained plant productivity of mulberry, a vital food source of silkworms. Despite its enormous potential, the application of AMF has not largely been adopted by mulberry growers. This affordable technology may help in making the mulberry an economically sustainable venture. There is enough scope for increasing AMF spore population in field through artificial inoculation of efficient indigenous strains to commercially exploit AMF for improvement in quantity and quality leaf production in mulberry at reduced rates of chemical P application. 


\section{References}

Abbasi H, Akhtar A, Sharf R. 2015. Vesicular arbuscular mycorrhizal (VAM) fungi: A tool for sustainable agriculture. American Journal of Plant Nutrition and Fertilization Technology 5(2): 40-49.

Al-Askar A, Rashad Y. 2010. Arbuscular mycorrhizal fungi: A biocontrol agent against common bean Fusarium root rot disease. Plant Pathology Journal 9: 31-38.

Ambika PK, Das PK, Katiyar RS, Choudhury PC. 1994. The influence of vesicular arbuscular mycorrhizal association on growth, yield and nutrient uptake in some mulberry genotypes (Morus spp.). Indian Journal of Sericulture 33: 166-169.

Augé RM. 2001. Water relations, drought and vesicular-arbuscular mycorrhizal symbiosis. Mycorrhiza 11(1): 3-42.

Augé RM. 2004. Arbuscular mycorrhizae and soil/plant water relations. Canadian Journal of Soil Science 84: 373-381.

Azcón-Aguilar C, Barea JM. 2015. Nutrient cycling in the mycorrhizosphere. Journal of Soil Science and Plant Nutrition 15: 372396.

Baby Summuna, Sheikh PA, Sachin Gupta, Dar WA, Dar GH. 2019. Diversity and distribution of arbuscular mycorrhizal fungi in pome and stone fruit orchards of North Western Himalayan state of Jammu \& Kashmir. Indian Phytopathology 72: 1-8.

Baqual MF, Das PK. 2006. Influence of biofertilizers on macronutrient uptake by the mulberry plant and its impact on silkworm bioassay. Caspian Journal of Environmental Sciences 4: 98-109.

Baqual MF, Das PK, Katiyar RS. 2005. Effect of arbuscular mycorrhizal fungi and other microbial inoculants on chlorophyll content of mulberry (Morus spp.). Mycorrhiza News 17(3): 12-14.

Baqual MF, Haque SZ, Mir MR, Ganai NA, Khan IL, Sharma RK. 2017. Use of biofertilizers in various agricultural crops with special reference to mulberry. International Journal of Advanced Biological Research 7: 1-10.

Battie-Laclau P, Taschen E, Plassard C, Dezette D, Abadie J, Arnal D, Laclau JP. 2019. Role of trees and herbaceous vegetation beneath trees in maintaining arbuscular mycorrhizal communities in temperate alley cropping systems. Plant and Soil 1-19. [https://doi.org/10.1007/s11104-01904181-z]

Beevi ND, Qadri SMH. 2010. Biological control of mulberry root rot disease (Fusarium spp.) with antagonistic microorganisms. Journal of Biopesticides 3 (Special issue): 90-92.

Begum N, Qin C, Ahanger MA, Raza S, Khan MI, Ahmed N, Zhang L. 2019. Role of arbuscular mycorrhizal fungi in plant growth regulation: Implications in abiotic stress tolerance. Frontiers in Plant Science 10: 1068.

Berruti A, Lumini E, Balestrini R, Bianciotto V. 2016. Arbuscular mycorrhizal fungi as natural biofertilizers: Let's Benefit from past successes. Frontiers in Microbiology 16: 19, January, article 1559.

Bhale UN, Bansode SA, Singh S. 2018. Multifacet role of arbuscular mycorrhizae in agroecosystem. In: Fungi and their Role in Sustainable Development: Current Perspectives. Springer, Singapore, pp. 205220.

Bharadwaj A, Sharma S. 2006. Reducing phosphorus requirement using AM fungi in mulberry grown under alkaline conditions. Journal of Agronomy 5: 471477.

Bhat A, Fatima A, Dar KA. 2018. Biocontrol and its role in sericulture: A review paper. International Journal of Advance Research in Science and Engineering 7: 1881-1885.

Birhane E, Gebremedihin KM, Tadesse T, Hailemariam M, Solomon N. 2017. Exclosures restored the density and root colonization of arbuscular mycorrhizal fungi in Tigray, Northern Ethiopia. Ecological Processes 6: 33-37.

Bothikar PA, Jadhav SS, Shinde YA. 2014. Growth and development of silk worm (Bombyx mori L.) on mulberry leaves. Journal of Industrial Pollution Control 30: 239-241.

Brundrett MC. 2009. Mycorrhizal associations and other means of nutrition of vascular plants: Understanding the global diversity of host plants by resolving conflicting 
information and developing reliable means of diagnosis. Plant and Soil 320: 37-77.

Cardoso Filho JA, Sobrinho RR, Pascholati SF. 2017. Arbuscular mycorrhizal symbiosis and its role in plant nutrition in sustainable agriculture. In: Agriculturally Important Microbes for Sustainable Agriculture. Springer, Singapore, pp. 129-164.

Chakraborty B, Chanda AK, Chakraborty SK. 2015. Effect of bio-organic amendments on the infestation of major pests and foliar disease, leaf productivity in mulberry (Morus alba L.). Journal of Experimental Agriculture International 7: 10-16.

Chen K, Shi SM, Yang XY, Huang XH. 2014. Contribution of arbuscular mycorrhizal inoculation to the growth and photosynthesis of mulberry in Karst rocky desertification area. Applied Mechanics and Materials 488-489: 769-773.

Chen M, Arato M, Borghi L, Nouri E, Reinhardt D. 2018. Beneficial services of arbuscular mycorrhizal fungi-from ecology to application. Frontiers in Plant Science 9: 1270.

Chen Y, Liu L, Guo Q, Zhu Z, Zhang L. 2016. Effects of different water management options and fertilizer supply on photosynthesis, fluorescence parameters and water use efficiency of Prunella vulgaris seedlings. Biological Research 49(1): 12.

Chowdhury PK, Setua GC, Ghosh A, Kar R, Maity SK. 2013. Sustainable quality leaf production in S 1635 mulberry (Morus alba) under irrigated condition through organic nutrient management. Indian Journal of Agricultural Sciences 83: 53-58.

CSRTI. 1992. Biofertilizers - Boon for sericulturists. CSRTI-News 1: 2, 1.

CSRTI. 2013. What are the advantages of VAM in mulberry cultivation?

[http://www.csrtimys.res.in/what-areadvantages-vam-mulberry-cultivation]

Dandin SB, Jayaswal J, Giridhar K. 2003. Handbook of Sericulture Technologies. Central Silk Board, Bangalore, India.

Dar GH. 2010. Soil Microbiology and Biochemistry. New India Publishing Agency, New Delhi, India.

Dar GH, Saba Banday, Beig MA, Nasreen Fatima.
2010. Efficacy of biocontrol agents in improving plant growth and control of root rot (Pythium ultimum Trow.) in apple. Plant Disease Research 24: 142-145.

Das KP, Katiyar RS, Hanumantha Gowda M, Fathima PS, Choudhury PC. 1995. Effect of vesicular arbuscular mycorrhizal inoculation on growth and development of mulberry (Morus spp.) saplings. Indian Journal of Sericulture 34: 15-17.

Declerck S, Séguin S, Dalpé Y. 2005. The monoxenic culture of arbuscular mycorrhizal fungi as a tool for germplasm collections. In: In vitro Culture of Mycorrhizas (eds. S. Declerck, D.G. Strullu and J.A. Fortin). Springer. Berlin, Heidelberg, Germany. pp. 17-30.

Dighton J, White JF. 2017. The Fungal Community: its Organization and Role in the Ecosystem. CRC Press. Florida, USA.

Egamberdieva D, Wirth SJ, Alqarawi AA, Abd_Allah EF, Hashem A. 2017. Phytohormones and beneficial microbes: Essential components for plants to balance stress and fitness. Frontiers in Microbiology 8: 2104.

Evelin H, Devi TS, Gupta S, Kapoor R. 2019. Mitigation of salinity stress in plants by arbuscular mycorrhizal symbiosis: Current understanding and new challenges. Frontiers in Plant Science 10: 470.

Evelin H, Kapoor R, Giri B. 2009. Arbuscular mycorrhizal fungi in alleviation of salt stress: A review. Annals of Botany 104: 1263-1280.

Fathima PS, Das PK, Katiyar RS. 2000. Effect of different levels and sources of phosphorus on VA mycorrhizal root colonization and spore load in mulberry (Morus alba L.). Crop Research (Hisar) 20: 504-508.

Fernandez GP, Espinosa RR, Martin GJM, Casanova KO, Alonso FA. 2014. Management of Canavalia ensiformis coinoculated with AMF and Rhizobium intercropped in mulberry (Morus alba L.) plantations. Rev Facultad Agron 31: 377392.

Finlay RD. 2008. Ecological aspects of mycorrhizal symbiosis: with special emphasis on the functional diversity of interactions involving the extraradical 
mycelium. Journal of Experimental Botany 59: 1115-1126.

Fogel R. 1988. Interactions among soil biota in coniferous ecosystems. Agriculture, Ecosystems \& Environment 24: 69-85.

Fortin JA, Declerck S, Strullu DG. 2005. In vitro culture of mycorrhizas. In: In vitro culture of mycorrhizas (eds. S. Declerck, D.G. Strullu and J.A. Fortin). Springer, Berlin, Heidelberg, Germany. pp. 3-14.

Galli U, Schüepp H, Brunold C. 1994. Heavy metal binding by mycorrhizal fungi. Physiologia Plantarum 92: 364-368.

Giovannini L, Palla M, Agnolucci M, Avio L, Sbrana C, Turrini A, Giovannetti M. 2020. Arbuscular mycorrhizal fungi and associated microbiota as plant biostimulants: Research strategies for the selection of the best performing inocula. Agronomy 10(1): 106.

Giovannini L, Sbrana C, Avio L, Turrini A. 2020. Diversity of a phosphate transporter gene among species and isolates of arbuscular mycorrhizal fungi. FEMS Microbiology Letters $367(2)$ : [https://doi.org/10.1093/femsle/fnaa024]

Göhre V, Paszkowski U. 2006. Contribution of the arbuscular mycorrhizal symbiosis to heavy metal phytoremediation. Planta 223: 1115-1122.

Gonzalez-Guerrero M, Melville LH, Ferrol N, Lott JN, Azcon-Aguilar C, Peterson RL. 2008. Ultrastructural localization of heavy metals in the extraradical mycelium and spores of the arbuscular mycorrhizal fungus Glomus intraradices. Canadian Journal of Microbiology 54: 103-110.

Goto BT, Silva GA, Assis D, Silva DK, Souza RG, Ferreira AC, Oehl F. 2012. Intraonatosporaceae (Gigasporales), a new family with two genera and two species. Mycotaxon 119: 117-132.

Gottshall CB, Cooper M, Emery SM. 2017. Activity, diversity and function of arbuscular mycorrhizae vary with changes in agricultural management intensity. Agriculture, Ecosystems \& Environment 241: 142-149.

Gupta MM, Aggarwal A. 2018. From mycorrhizosphere to rhizosphere microbiome: The paradigm shift. In: Root
Biology. Springer, Cham, Switzerland. pp. 487-500.

Gupta RD, Arora S. 2015. Agroforestry as alternate landuse system for sustaining rural livelihoods in Himalayan ecosystem. In: Advances in Soil and Water Resource Management for Food and Livelihood Security in Changing Climate (Eds. S. Bhan and S. Arora). Soil Conservation Society of India, New Delhi, India. pp. 656-669.

Hatfield JL. 2018. Soil Biology: Effects on Soil Quality. CRC Press, New York, USA.

Higo M, Isobe K, Yamaguchi M, Drijber RA, Jeske ES, Ishii R. 2013. Diversity and vertical distribution of indigenous arbuscular mycorrhizal fungi under two soybean rotational systems. Biology and Fertility of Soils 49: 1085-1096.

Ijdo M, Cranenbrouck S, Declerck S 2011. Methods for large-scale production of AM fungi: Past, present, and future. Mycorrhiza 21: 1-16.

International Sericultural Commission. 2019. Statistics - Global Silk Industry. (www.inserco.org/en/statistics).

Jambhulkar PP, Sharma P, Yadav R. 2016. Delivery systems for introduction of microbial inoculants in the field. In: Microbial Inoculants in Sustainable Agricultural Productivity. Springer, New Delhi, India. pp. 199-218.

Jeffries P, Gianinazzi S, Perotto S, Turnau K, Barea J. 2003. The contribution of arbuscular mycorrhizal fungi in sustainable maintenance of plant health and soil fertility. Biology \& Fertility of Soils 37: 116.

Johnson D, Leake JR, Read DJ. 2002. Transfer of recent photosynthate into mycorrhizal mycelium of an upland grassland: Shortterm respiratory losses and accumulation of ${ }^{14}$ C. Soil Biology \& Biochemistry 34: 15211524.

Kashyap S, Sharma S, Vasudevan P. 2004. Role of bioinoculants in development of saltresistant saplings of Morus alba (var. sujanpuri) in vivo. Scientia Horticulturae 100: 291-307.

Katiyar RS, Das PK, Choudhury PC. 1999. VAmycorrhizal inoculation of established mulberry garden through maize (Zea mays) 
intercropping: An effective technique. In: National Conference on Moriculture: Physiological, Biochemical and Molecular Aspects of Stress Tolerance in Mulberry. 22-23 February, 1999, Trchy. India. p. 854.

Katiyar RS, Das PK, Choudhury PC, Ghosh A, Singh GB, Datta RK. 1995. Response of irrigated mulberry (Morus alba L.) to VA mycorrhizal inoculation under graded doses of phosphorus. Plant and Soil 170: 331-337.

Kehri HK, Akhtar O, Zoomi I, Pandey D. 2018. Arbuscular mycorrhizal fungi: Taxonomy and its systematics. International Journal of Life Science Research 6(4): 58-71.

Kilvin SN, Hawkes CV. 2016. Arbuscular mycorrhizal fungi influence long-term plant-soil feedbacks as much as soil pathogens in Neotropical forests. Environmental Microbiology 18: 46624673.

Kaur R, Mir MR, Mir NA, Khan MA, Darzi GM, Farooq M. 2009. Impact of arbuscular mycorrhiza fungal inoculation on growth and development of mulberry (Morus spp.) saplings under Kashmir conditions. Applied Biological Research 11: 49-52.

Kumaresan S, Elumalai S, Prabhakaran M. 2010. Effect of VAM fungi on growth and physiological parameters of mulberry (Morus alba L.) cultivars in South India. Biosciences, Biotechnology Research Asia 7: 793-806.

Kumari NV, Sujathamma P. 2011. Combined efficacy of VAM and Verticillium chlamidosporwm on root knot nematode Meloidogyne incognita Chitwood. in mulberry (Morus spp.). Bulletin of Indian Academy of Sericulture 15(2): 61-66.

Kumutha K. 2001. Symbiotic Influence of AM Fungi and Rhizobacteria on Biochemical and Nutritional Changes in Mulberry (Morus alba L.). Ph.D. thesis, Tamil Nadu Agricultural University, Coimbatore, India.

Lambers H, Albornoz F, Kotula L, Laliberté E, Ranathunge K, Teste FP, Zemunik G. 2018. How belowground interactions contribute to the coexistence of mycorrhizal and nonmycorrhizal species in severely phosphorus-impoverished hyperdiverse ecosystems. Plant and Soil 424: 11-33.

Lambers H, Shane MW, Cramer MD, Pearse SJ,
Veneklaas EJ. 2006. Root structure and functioning for efficient acquisition of phosphorus: Matching morphological and physiological traits. Annals of Botany 98: 693-713.

Lehmann A, Leifheit EF, Rillig MC. 2017. Mycorrhizas and soil aggregation. In: Mycorrhizal Mediation of Soil: Fertility, Structure and Carbon Storage. Elsevier. pp. 241-262.

Li X, Sun M, Zhang H, Xu N, Sun G. 2016. Use of mulberry-soybean intercropping in saltalkali soil impacts the diversity of the soil bacterial community. Microbial Biotechnology, 9(3): 293-304.

Liu CY, Zhang F, Zhang DJ, Srivastava AK, Wu QS, Zou YN. 2018. Mycorrhiza stimulates root-hair growth and IAA synthesis and transport in trifoliate orange under drought stress. Scientific Reports 8: 1-9.

Lu N, Zhou X, Cui M, Yu M, Zhou JX, Qin YS. 2015. Colonization with arbuscular mycorrhizal fungi promotes the growth of Morus alba L. seedlings under greenhouse conditions. Forests 6: 734-747.

Shankar MA, Jayaramaiah M, Anitha P, Rangaswamy BT, Lingappa BS, Mallikarjuna GB, Peter A. 1999. An overview of mulberry cultivation practices adopted by sericulturists in Karnataka. Mysore Journal of Agricultural Sciences 32: 208-215.

Machii H, Katagiri K. 1991. Varietal differences in nutritive values of mulberry leaves for rearing silkworms. Japan Agricultural Research Quarterly 25: 202-208.

Mamatha G, Bagyaraj DG, Jaganath S. 2002. Inoculation of field-established mulberry and papaya with arbuscular mycorrhizal fungi and a mycorrhiza helper bacterium. Mycorrhiza 12: 313-316.

Mary LCL. 2012. Effect of Biofertilizers on Nutrient Availability in Soil and Mulberry Leaf and its impact on the Rearing and Quality Improvement of Silk in Bombyx mori (L.). Ph.D. thesis, Bharathidasan University. Tirucherapalli, Tamil Nadu, India. [http://hdl.handle.net/123456789/16039].

Miller RM, Jastrow JD. 1992. The role of mycorrhizal fungi in soil 
conservation. Mycorrhizae in Sustainable Agriculture 54: 29-44.

Wilson GW, Rice CW, Rillig MC, Springer A, Hartnett DC. 2009. Soil aggregation and carbon sequestration are tightly correlated with the abundance of arbuscular mycorrhizal fungi: Results from long- term field experiments. Ecology Letters 12: 452461.

Miller RM, Lodge DJ. 1997. Fungal responses to disturbance: Agriculture and forestry. The Mycota, 4: 65-84.

Mohamed SA, Massoud ON. 2017. Impact of inoculation with mycorrhiza and Azotobacter under different $\mathrm{N}$ and $\mathrm{P}$ rates on growth, nutrient status, yield and some soil characteristics of Washington Navel Orange trees. Middle East Journal of Agriculture Research 6: 617-638.

Morton JB, Benny GL. 1990. Revised classification of arbuscular mycorrhizal fungi (Zygomycetes): A new order, Glomales, two new suborders, Glomineae and Gigasporineae, and two new families, Acaulosporaceae and Gigasporaceae, with an emendation of Glomaceae. Mycotaxon 37: 471-491.

Nogueira MA, Magalhães GC, Cardoso EJ. 2004. Manganese toxicity in mycorrhizal and phosphorus-fertilized soybean plants. Journal of Plant Nutrition 27: 141156.

Ordoñez YM, Fernandez BR, Lara LS, Rodriguez A, Uribe-Velez D, Sanders IR. 2016. Bacteria with phosphate solubilizing capacity alter mycorrhizal fungal growth both inside and outside the root and in the presence of native microbial communities. PloS one 11(6). e0154438. [https://doi.org/10.1371/journal.pone.0154 438].

Padma SD, Sukumar J. 2015. Response of mulberry to inoculation of potash mobilizing bacterial isolate and other bioinoculants. Global Journal of Bioscience and Biotechnology 4: 50-53.

Padma SD, Sukumar J, Kumar TDN, Bongale UD. 1999. Effect of vesicular arbuscular mycorrhiza, Azotobacter and Biophos on the growth of mulberry saplings. International Journal of Tropical
Agriculture 17: 183-187.

Pan SYFYJ, Huang CYYXH, Jian XZQ. 2011. Developmental features of mycorrhiza and its promotion effect on growth of mulberry saplings in three Gorges Reservoir Region. Science of Sericulture 6: [http://en.cnki.com.cn/Article_en/CJFDTot al-CYKE201106001.htm].

Pentón G, Martín GJ, Rivera R. 2014. Effect of the combination of $\mathrm{AMF}$ and chemical fertilization on the extractions of $\mathrm{N}$ and $\mathrm{K}$ made by Morus alba. Pastos y Forrajes 37: 38-46.

Pentón G, Martín GJ, Rivera R, Martín GM, Machado R, Herrera JA. 2016. Effect of cutting interval and nutrition management in mulberry [Morus alba (L.)]. I. Forage production. Pastures and Forages, 9(2): [https://payfo.ihatuey.cu/index.php?journal $=$ pasto $\&$ page $=$ article $\&$ op $=$ download $\&$ pat $h \% 5 B \% 5 D=1872 \&$ path\% $5 B \% 5 D=2782 \& i$ nline $=1]$

Pentón G, Oropesa K, Peñalver PL. 2013. Multiplication of AMF infective propagules in a mulberry (Morus alba L.) plantation. Pastos y Forrajes 36: 22-32

Pentón G, Rivera R, Martín GJ, Aracelis M, Alonso F, Medina A. 2014. Effect of mycorrhizal symbiosis, chemical fertilizat0ion and their combination, on the soil-plant relation of mulberry. Pastos y Forrajes 37, 399-407.

Peterson RL, Massicotte HB, Melville LH. 2004. Mycorrhizas: Anatomy and Cell Biology. NCR Research Press, Ottawa, Canada.

Petkov Z. 2016. Mulberry - Excellent food not only for silkworms. Bulgarian Journal of Animal Husbandry 53: 81-87.

Piao H, Li S, Wang S. 2016. Nutrient uptake by mulberry and Chinese prickly ash associated with arbuscular mycorrhizal fungi. Acta Geochimica 35: 120-129.

Porcel R, Aroca R, Ruiz-Lozano JM. 2012. Salinity stress alleviation using arbuscular mycorrhizal fungi. A review. Agronomy for Sustainable Development 32: 181-200.

Pozo MJ, Azcón-Aguilar C. 2007. Unraveling mycorrhiza-induced resistance. Current Opinion in Plant Biology 10: 393-398.

Quoreshi AM. 2008. The use of mycorrhizal biotechnology in restoration of disturbed 
ecosystem. In: Mycorrhizae: Sustainable Agriculture and Forestry. Springer, Dordrecht, Germany. pp. 303-320.

Rajagopal D, Madhavendra SS, Jamil K. 1989. Occurrence of vesicular-arbuscular mycorrhizal fungi in roots of Morus alba L. Current Science 58: 687-689.

Rajaram S, Patton MA, Roy Chowdhuri S, Kumar SN. 2014. Studies on mass multiplication of Glomus mosseae [arbuscular mycorrhizal fungus] for 'Phosphoret' biofertilzer production, its efficacy on phosphatic fertilizer saving and productivity in high yielding mulberry garden under West Bengal conditions. Research Inventy: International Journal of Engineering and Science 4(3): 25-35.

Ram Rao DR, Kodandaramaiah J, Reddy M, Katiyar R, Rahmathulla V. 2007. Effect of VAM fungi and bacterial biofertilizers on mulberry leaf quality and silkworm cocoon characters under semiarid conditions. Caspian Journal of Environmental Sciences 5: 111-117.

Rao NS. (Ed.). 2016. Advances in Agricultural Microbiology. Elsevier, USA.

Reddy MP, Ram Rao DM, Verma RS, Srinath B, Katiyar RS. 1998. Response of S 13 mulberry variety to VAM inoculum under semiarid condition. Indian Journal of Plant Physiology 3: 194-196.

Reddy MP, Ram Rao DM, Katiyar RS, Suryanarayana N. 2000. Economization of $\mathrm{N}$ and $\mathrm{P}$ fertilizers through dual inoculation of VAM and bacterial biofertilizers in farmers field of Andhra Pradesh. In: Proceedings of the National Conference on Strategies for Sericulture Research and Development. 16-18 Nov., 2000. Adv. in Indian Seri. Res., pp. 212-215.

Ruiz-Lozano JM, Azcón R, Gomez M. 1995. Effects of arbuscular-mycorrhizal glomus species on drought tolerance: Physiological and nutritional plant responses. Applied \& Environmental Microbiology 61: 456-460.

Saima Khursheed 2017. Fluctuations in arbuscular mycorrhizal population with seasons in rhizosphere of mulberry gardens of Kashmir. pp. 407-414. In: International Conference on Recent Innovations in Science, Agriculture, Engineering and
Management. 20 Nov., 2017. University College of Computer Applications, Guru Kashi University, Bathinda, Punjab, India. [www.conferenceworld.in]

Sakthivel N, Ravikumar J, Kirsur CMV, Bindroo BB, Sivaprasad Shankar V. 2014. Organic Farming in Mulberry: Recent Breakthrough. Regional Sericultural Research Station, Central Silk Board, Govt. of India, Salem, Tamil Nadu, India.

Saranya K, Kumutha K. 2011. A critical review on arbuscular mycorrhizal fungi and soil properties in natural systems. International Journal of Current Research 33 (5): 32-38.

Sarkar A, Jalaja SK, Datta RK. 2000. Gradual improvement of mulberry varieties under irrigated conditions in south India and the optimal program for varietal selection in the tropics. Sericologia 40: 440-446.

Schutzendubel A, Polle A. 2002. Plant responses to abiotic stresses: Heavy metal- induced oxidative stress and protection by mycorrhization. Journal of Experimental Botany, 53(372): 1351-1365.

Seth MK. 2003. Trees and their economic importance. Botanical Reviews 69: 321376.

Setua GC, Banerjee ND, Das NK, Ghosh JK, Saratchandara B. 2003. Effect of direct application of arbuscular mycorrhizal fungi in mulberry (Morus alba L.) under irrigated condition. Bulletin of Indian Academy of Sericulture 7: 60-64.

Setua GC, Das KK, Ghosh JK, Saratchandra B. 2001. Seasonal variation in the association of arbuscular mycorrhizae with mulberry (Morus alba L.). Journal of Mycopathological Research 39: 29-34.

Setua GC, Kar R, Ghosh A, Das NK, Saratchandra B. 1999a. Response of direct inoculation of VAM on growth, leaf yield and phosphorus uptake in mulberry (Morus $a l b a$ ). Indian Journal of Agricultural Sciences 69: 444-448.

Setua GC, Kar R, Ghosh JK, Das NK, Sen SK. 1999b. Influence of arbuscular mycorrhizae on growth, leaf yield and phosphorus uptake in mulberry (Morus alba L.) under rainfed, lateritic soil conditions. Biology \& Fertility of Soils 29: 98-103.

Setua GC, Setua M, Debnath S, Chowdhury PK, 
Misra AK, Ghosh A. 2009. Comparative efficacy of different strains of arbuscular mycorrhizal fungi on growth, leaf yield and quality of mulberry (Morus alba L.) var. S1 under irrigated condition. Journal of Interacademicia 13: 11-18.

Setua GC, Setua M, Ghosh A, Debnath S, Dutta AK, Banerjee ND. 2007. Effect of integrated nutrient management on sustainable quality leaf production in mulberry (Morus alba) under irrigated, alluvial soil conditions. Indian Journal of Agricultural Sciences 77: 286-290.

Sharma DD, Govindaiah S, Katiyar RS, Das PK, Janardhan L, Bajpai AK, Choudhary PC, Janardhan L. 1995. Effect of VAmycorrhizal fungi on the incidence of major mulberry diseases. Indian Journal of Sericulture 34: 34-37.

Shi SM, Chen K, Tu B, Yang XH, Huang XZ. 2013. Diversity of AMF in mulberry rhizosphere in a rock desertification area and vigorous mulberry seedling culture. Journal of Southwest University $35: 1-8$.

Shi SM, Chen K, Gao Y, Liu B, Yang XH, Huang XZ, Liu GX, Zhu LQ, He XH. 2016. Arbuscular mycorrhizal fungus species dependency governs better plant physiological characteristics and leaf quality of mulberry (Morus alba L.) seedlings. Front. Microbiol., 28 June 2016. | https://doi.org/10.3389/fmicb.2016.01030]

Smith SE, Read DJ. 2008. Mycorrhizal Symbiosis, ( $3^{\text {rd }}$ Edn.). Academic Press, San Diego, USA.

Souza T. 2015. Handbook of Arbuscular Mycorrhizal Fungi. Springer. Cham, Switzerland.

Sudhakar P, Swamy Gowda MR, Jalaja SK, Sobhana V, Sivaprasad V. 2018. Fertility status of mulberry (Morus alba L.) garden soils of bivoltine sericultural areas and their impact on cocoon production in Karnataka. International Journal of Development Research 8: 19231-19236.

Sujan Singh 1998. Interaction of mycorrhizae with soil microflora and microfauna - Part II. Interaction with free-living nitrogen fixers and soil microfauna. Mycorrhiza News 10 (2): 2-11.
Sujathamma P, Dandin SB. 2000. Leaf quality evaluation of mulberry (Morus spp.) through chemical analysis. Indian Journal of Sericulture 39: 117-121.

Sukumar J, Padma SD. 1999. Disease of mulberry in India - Research progress and priorities. In: Advances in Mulberry Sericulture (eds. M.C. Devaiah, K.C. Narayanaswamy and V.G. Maribashetty), C.V.G. Publications, Bangalore, India. pp. 152-186.

Supriya G, Purshotam K. 2012. Effect of seasonal variation on mycorrhizal fungi associated with medicinal plants in central Himalayan region of India. American Journal of Plant Sciences 3: 618-626.

Tabunoki H, Higurashi S, Ninagi O, Fujii H, Banno Y. Nozaki M. 2004. A carotenoidbinding protein $(\mathrm{CBP})$ plays a crucial role in cocoon pigmentation of silkworm (Bombyx mori) larvae. FEBS Letters 567: 175-178.

Tahat MM, Sijam, Kamaruzaman, Othman R. 2010. Mycorrhizal fungi as a biocontrol agent. Plant Pathology Journal 9: 198-207.

Tang X, Liu DJ, Tu B, Yang XH, Huang XZ. 2013. Promotion effect on growth of mycorrhiza-inoculated mulberry saplings and physiological and biochemical mechanism to drought tolerance. Journal of Southwest University 35: 19-26.

Taylor B, Strand A, Cooper ER, Beidler K, Schönholz M, Pritchard S. 2014. Root length, biomass, tissue chemistry and mycorrhizal colonization following 14 years of $\mathrm{CO}_{2}$ enrichment and 6 years of $\mathrm{N}$ fertilization in a warm temperate forest. Tree Physiology 34: 955-965.

Thimmareddy H, Prabhuraj DK, Bongale UD, Dandin SB. 1999. Fertility status of mulberry growing soils in Mysore seed area. Karnataka Indian Journal of Sericulture 38: 26-29.

Todeschini V, AitLahmidi N, Mazzucco E, Marsano F, Gosetti F, Robotti E, Wipf D. 2018. Impact of beneficial microorganisms on strawberry growth, fruit production, nutritional quality and volatilome. Frontiers in Plant Science 9: 1611-1617.

Treseder KK. 2013. The extent of mycorrhizal colonization of roots and its influence on plant growth and phosphorus content. Plant 
\& Soil 371: 1-13.

Trouvelot S, Bonneau L, Redecker D, Van Tuinen D, Adrian M, Wipf D. 2015. Arbuscular mycorrhiza symbiosis in viticulture: A review. Agronomy for Sustainable Development 35: 1449-1467.

Umakanth CG, Bagyaraj DJ. 1998. Response of mulberry saplings to inoculation with VA mycorrhizal fungi and Azotobacter. Sericologia 38: 669-675.

Verbruggen E, Toby Kiers E. 2010. Evolutionary ecology of mycorrhizal functional diversity in agricultural systems. Evolutionary Applications 3: 547-560.

Vijaya Kumari N. 2014. Ecofriendly technologies for disease and pest management in mulberry - A review. IOSR Journal of Agriculture and Veterinary Science 7(2): 16.

Vogelsang KM, Bever JD, Griswold M, Schultz PA. 2004. The Use of Mycorrhizal Fungi in Erosion Control Applications. Indiana University Department of Biology, Bloomington, Indiana.

Vosátka M, Látr A, Gianinazzi S, Albrechtová J. 2013. Development of arbuscular mycorrhizal biotechnology and industry: Current achievements and bottlenecks. Symbiosis 58: 29-37.

Wahid F, Sharif M, Steinkellner S, Khan MA, Marwat KB, Khan SA. 2016. Inoculation of arbuscular mycorrhizal fungi and phosphate solubilizing bacteria in the presence of rock phosphate improves phosphorus uptake and growth of maize. Pakistan Journal of Botany 48: 739-747.

Willis A, Rodrigues BF, Harris PJ. 2013. The ecology of arbuscular mycorrhizal fungi. Critical Reviews in Plant
Sciences 32: 1-20.

Wu QS. (Ed.). 2017. Arbuscular Mycorrhizas and Stress Tolerance of Plants Springer. Singapore

Xing D, Wang Z, Xiao J, Han S, Luo C, Zhang A, Song L, Gao X. 2018. The composition and diversity of arbuscular mycorrhizal fungi in Karst soils and roots collected from mulberry of different ages. Ciencia Rural $48 \quad$ (10): $\quad$ Epub Oct 25, 2018 [http://dx.doi.org/10.1590/01038478cr20180361].

Zargar MY, Dar GH, Zargar AH. 2000. Mycorrhizae in relation to ecosystem development. In: Environment, Biodiversity and Conservation (ed. M.A. Khan and S. Farooq), A.P.H. Publ., New Delhi, India. pp. 465-478.

Zeng P, Guo Z, Xiao X, Peng C. 2019. Dynamic response of enzymatic activity and microbial community structure in metal(loid)-contaminated soil with treeherb intercropping. Geoderma 345: 5-16.

Zhang $\mathrm{M}$, Wang Z, Wang $\mathrm{N}$, Zhang $\mathrm{J}$, Hu $\mathrm{H}$, Yanbo H, Cai D, Guo J, Wu D, Sun G. 2019. Soil physicochemical properties and the rhizosphere soil fungal community in a mulberry (Morus alba L.)/ alfalfa (Medicago sativa L.) intercropping system. Forests 10: 167-180.

Zhang XH, Lin AJ, Gao YL, Reid RJ, Wong MH, Zhu YG. 2009. Arbuscular mycorrhizal colonisation increases copper binding capacity of root cell walls of Oryza sativa L. and reduces copper uptake. Soil Biology \& Biochemistry 41: 930-935.

\section{How to cite this article:}

Ghulam Hassan Dar and Pankaj Dunge. 2020. Role of Arbuscular Mycorrhizal Fungi in Mulberry Ecosystem Development. Int.J.Curr.Microbiol.App.Sci. 9(05): 13-37. doi: https://doi.org/10.20546/ijcmas.2020.905.002 